\title{
Downregulated miR-486-5p acts as a tumor suppressor in esophageal squamous cell carcinoma
}

\author{
YUNFENG YI, XIUJUAN LU, JIANMING CHEN, CHANGJIE JIAO, JING ZHONG, \\ ZHIMING SONG, XIAOPING YU and BAOLI LIN
}

Department of Thoracic Surgery, Dongnan Affiliated Hospital of Xiamen University, Zhangzhou, Fujian 363000, P.R. China

Received May 14, 2015; Accepted July 15, 2016

DOI: $10.3892 /$ etm.2016.3783

\begin{abstract}
RNAs (miRNAs/miRs) are crucial regulators of gene expression at the post-translational level through promoting mRNA degradation or the repression of translation of target genes. miRs have been confirmed to serve a dominant role in tumor biology. miR-486-5p has been ascertained to be involved in non-small-cell lung cancer, breast cancer and hepatocellular carcinoma; however, the expression and function of miR-486-5p in esophageal squamous cell carcinoma (ESCC) has yet to be elucidated. The present study aimed to analyze the expression levels of miR-486-5p in ESCC tissues and paired normal adjacent tissues, and determine the effects of miR-486-5p on esophageal cancer cells using MTT, wound scratch and apoptosis assays. The current results showed that miR-486-5p was significantly downregulated in ESCC specimens. Ectopic expression of miR-486-5p by synthetic mimics reduced cell proliferation and migration and induced increased cell apoptosis. The results indicated miR-486-5p may function as a tumor suppressor in ESCC. The present study demonstrated that miR-486-5p was downregulated in ESCC and served a anti-oncogene role in ESCC via affecting cellular migration.
\end{abstract}

\section{Introduction}

Esophageal cancer is the eighth most common type of cancer and the sixth leading cause of cancer-associated mortality worldwide (1-3). Esophageal cancer incidence in men is higher compared with that in women, and its occurrence increases with age, and mortality rate is $\sim 90 \%$ for all cases $(1,2,4)$. Esophageal squamous cell carcinoma (ESCC) is the predominant histological type amongst Chinese populations, resulting

Correspondence to: Professor Jianming Chen, Department of Thoracic Surgery, Dongnan Affiliated Hospital of Xiamen University, 269 Zhanghuazhong Road, Zhangzhou, Fujian 363000, P.R. China

E-mail: chenjianming321@126.com

Key words: esophageal squamous cell carcinoma, miR-486-5p, downregulated, tumor suppressor in 150,000 cases of mortality annually (5). Despite advances in medical and surgical techniques, the prognosis for ESCC remains poor, and long-term survival is in the range of 26.2-49.4\% due to local or distant recurrences (6). Therefore, it is critical to identify novel molecular mechanisms to elucidate oncogenesis and metastasis in ESCC.

MicroRNAs (miRNAs/miRs) are small (18-22 nucleotide) endogenous non-coding RNAs that serve crucial roles in various biological processes $(7,8)$. Mature miRNAs usually bind to the 3'-untranslated regions of target genes to downregulate the expression of target genes at post-transcriptional levels through promotion of mRNA degradation or repression of the translation of target genes $(7,9)$. Since miRNA-lin-4 was initially identified in 1993, numerous miRNAs have been ascertained to be involved in various physiological and pathological processes, including carcinogenesis (10). Several miRNAs such as miR-21, miR-34a and miR-155 have been found to be associated with carcinogenesis by targeting oncogenes or anti-oncogenes (11-13).

Recently, miR-486-5p has been reported to function as a tumor suppressor in non-small-cell lung cancer (NSCLC) (14), breast cancer (15) and hepatocellular carcinoma (16). However, the function and clinical significance of miR-486-5p in ESCC has yet to be elucidated (15). In the present study, the expression levels of miR-486-5p in ESCC tissues were determined, and the function of miR-486-5p in ESCC cells were investigated by cell migration, proliferation and apoptosis assays. The results indicated that miR-486-5p was downregulated in ESCC tissues and functioned as an anti-oncogene in ESCC by affecting cellular migration, proliferation and apoptosis.

\section{Materials and methods}

ESCC tissue sample collection. All ESCC and adjacent normal tissues used in the present study were collected in Dongnan Affiliated Hospital of Xiamen University (Zhangzhou, China). Written informed consent was obtained from all patients. Ethical approval for the collection and use of all samples was approved by the Ethics Committee of Dongnan Affiliated Hospital of Xiamen University. Fresh tissues were immersed in RNAlater (Qiagen $\mathrm{GmbH}$, Hilden, Germany) in $30 \mathrm{~min}$ after resection and subsequently stored at $-80^{\circ} \mathrm{C}$ for future use. 
Cell culture and transfection. Human ESCC cell lines Eca109 and TE-1 were purchased from the Shanghai Institute of Biochemistry and Cell Biology (Shanghai, China). Eca109 and TE-1 were cultured in RPMI 1640 (Invitrogen) supplemented with $10 \%$ fetal bovine serum (Invitrogen), $100 \mathrm{U} / \mathrm{ml}$ penicillin and $100 \mathrm{~g} / \mathrm{ml}$ streptomycin (Gibco; Thermo Fisher Scientific, Inc.), at $37^{\circ} \mathrm{C}$ for $24 \mathrm{~h}$ in a humidified incubator containing $5 \% \mathrm{CO}_{2}$. For the restoration of miR-486-5p in ESCC tissues with endogenously downregulated miR-486-5p, synthesized miR-486-5p mimics (GenePharma Co., Ltd., Shanghai, China) was transfected into cells using Lipofectamine 2000 (Invitrogen) according to the manufacturer's protocol. The cells were trypsinized, and total RNA was extracted using TRIzol reagent (Invitrogen; Thermo Fisher Scientific, Inc., Waltham, MA, USA) $24 \mathrm{~h}$ after transfection.

$R N A$ isolation and reverse transcription-quantitative polymerase chain reaction ( $R T-q P C R)$ assays. Total RNA was extracted from 36 ESCC tissue samples and adjacent normal esophageal tissues, or from the trypsinized ESCC cell lines Eca109 and TE-1, using TRIzol reagent (Invitrogen), and purified using an RNeasy Maxi Kit (Qiagen $\mathrm{GmbH}$ ) according to the manufacturer's protocol. To obtain the cDNA templates, $1 \mu \mathrm{g}$ total RNA of each sample was used for reverse transcription using an miScript Reverse Transcription kit (Qiagen $\mathrm{GmbH}$ ). This reaction was performed at $37^{\circ} \mathrm{C}$ for $60 \mathrm{~min}$, then $95^{\circ} \mathrm{C}$ for $5 \mathrm{~min}$. The qPCR reaction of miR-486-5p was performed on an ABI PRISM 7000 Fluorescent Quantitative PCR System (Applied Biosystems; Thermo Fisher Scientific, Inc., Waltham, MA, USA) using miScript SYBR Green PCR Kit (Qiagen $\mathrm{GmbH}$ ). The $20 \mu \mathrm{l}$ reaction mixture contained $1 \mu \mathrm{l}$ cDNA template, $2 \mu 1 \mathrm{10X}$ miScript Universal Primer, $0.4 \mu \mathrm{l}$ of each of the specific miRNA primers, $10 \mu \mathrm{l} 2 \mathrm{X}$ QuantiTect SYBR Green PCR Master mix and 6.6 $\mu 1$ RNasefree water. Primer sequences were as follows: Forward, 5'-TCCTGTACTGAGCTGCCCCGAG-3' [the reverse primer was provided by the miScript SYBR Green PCR Kit (Qiagen $\mathrm{GmbH})]$ for miR-486-5p; and forward, 5'-CTCGCTTCG GCAGCACA-3' and reverse, 5'-ACGCTTCACGAATTT GCGT-3', for U6 (U6 was used as an endogenous control in the present study). Amplification conditions were set as follows: $95^{\circ} \mathrm{C}$ for $2 \mathrm{~min}$, followed by $95^{\circ} \mathrm{C}$ for $15 \mathrm{sec}, 58^{\circ} \mathrm{C}$ $30 \mathrm{sec}$ and $72^{\circ} \mathrm{C}$ for $30 \mathrm{sec}$, for 40 cycles. This experiment was repeated 3 times, with accompanying no cDNA and no reverse transcriptase controls. The expression of miR-486-5p was analyzed using the $\Delta \Delta \mathrm{Cq}$ method (17), normalizing to U6 expression.

Migration assay. A wound scratch assay was used to assess the migratory ability of Eca109 and TE-1 cells in vitro. Cells $(\sim 150,000)$ were seeded into a 12-well dish and transfected with miR-486-5p mimics (60 pmol) or the negative, scrambled control (60 pmol) (GenePharma Co., Ltd.) $24 \mathrm{~h}$ later. A sterile $200 \mu$ l pipette tip was used to scrape a clear line through the cell monolayer $5 \mathrm{~h}$ post-transfection. The cells were then rinsed three times with phosphate-buffered saline (PBS) and cultured in an incubator at $37^{\circ} \mathrm{C}$. Images of the wound scratches were acquired with an inverted light microscope (DM IRB; Leica Microsystems GmbH, Wetzlar, Germany) at 0 and $24 \mathrm{~h}$ after the wounds were made. The migration distance $(\mu \mathrm{m})$ was measured with a standard caliper and the experiments were performed in triplicate and analyzed by at least two observers.

MTT assay. The cell proliferation of Eca109 and TE-1 cells was determined with MTT assay kit (Sigma-Aldrich, St. Louis, MO, USA). To determine cell growth, $\sim 5,000$ cells were seeded into the wells of 96 -well plates and transfected with miR-486-5p mimics (5 pmol) or the negative, scrambled control (5 pmol). MTT (20 $\mu \mathrm{l} ; 5 \mathrm{mg} / \mathrm{ml}$; Sigma-Aldrich) was added to each well at $0,24,48$ and $72 \mathrm{~h}$ after transfection. Subsequent to incubation for $4 \mathrm{~h}$, the MTT medium was removed and $150 \mu 1$ dimethyl sulfoxide was added. After shaking for $15 \mathrm{~min}$ at room temperature, the optical density (OD) of each sample was determined with an Enzyme Immunoassay Instrument (Model 680 microplate reader; Bio-Rad Laboratories, Inc., Hercules, CA, USA) at a wavelength of $490 / 630 \mathrm{~nm}$.

Flow cytometry. For apoptosis assays, Eca109 and TE-1 cells were cultured in 6 -well plates at $37^{\circ} \mathrm{C}$ to a confluence of $\sim 65 \%$ and transfected with miR-486-5p mimics or a negative control. After $48 \mathrm{~h}$ of transfection, Eca109 and TE-1 cells were harvested and washed twice with cold PBS, then resuspended in $10 \mu 11 \mathrm{X}$ binding buffer (Invitrogen). Annexin V-FITC (5 $\mu \mathrm{l}$; Invitrogen) and $10 \mu \mathrm{l}$ propidium iodide was added to each sample. According to the manufacturer's protocol, the fluorescence of stained cells was then assessed by flow cytometer (Beckman Coulter, Inc., Brea, CA, USA) using $488 \mathrm{~nm}$ excitation within $30 \mathrm{~min}$.

Statistical analysis. Statistical analysis was performed using the SPSS statistical software package (version 17.0; SPSS, Inc., Chicago, IL, USA). Statistical significance was determined by paired and Student's t-tests. $\mathrm{P}<0.05$ and $\mathrm{P}<0.01$ were considered to indicate a statistically significant difference.

\section{Results}

miR-486-5p expression levels were downregulated in ESCC tissues. RT-qPCR was used to determine expression levels of miR-486-5p in 35 paired ESCC tissues and adjacent normal tissues. The relative expression of miR-486-5p in the 35 paired ESCC tissues and adjacent normal tissues are shown in Fig. 1A. miR-486-5p expression in ESCC tissues was significantly downregulated compared with those of the paired adjacent normal tissues $(\mathrm{P}<0.05)$ (Fig. 1B).

Transfection efficiency. To analyze the function of miR-486-5p in ESCC, miR-486-5p mimics and negative controls were transfected into the ESCC cell lines, Eca109 and TE-1. Images of cells transfected with Fam-labeled negative control were obtained $6 \mathrm{~h}$ after transfection. As shown in Fig. 2A, the transfection efficiency was $\sim 80$ and $\sim 85 \%$ in Eca109 and TE-1 cells, respectively. Compared with the negative control, the relative expression levels of miR-486-5p in Eca109 and TE-1 cells transfected with miR-486-5p mimics were 94- and 103 -fold, respectively $(\mathrm{P}<0.05$; Fig. $2 \mathrm{~B})$. The results demonstrated that miR-486-5p mimics were effective in upregulating the expression of miR-486-5p. 
A

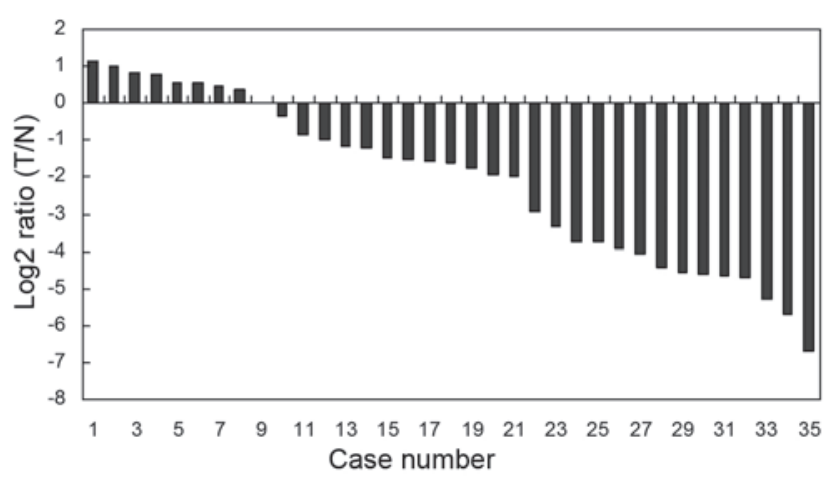

B

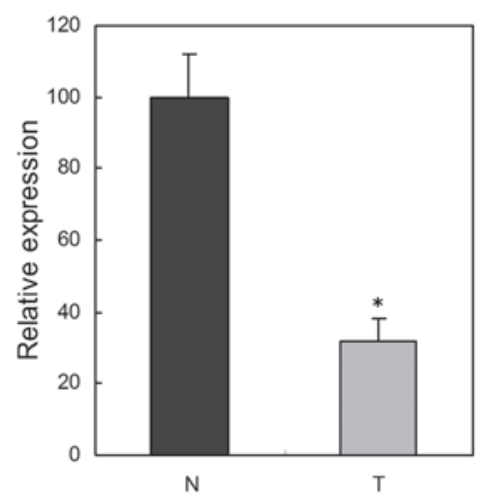

Figure 1. Expression levels of miR-486-5p in 35 paired esophageal squamous cell carcinoma (ESCC) tissues and adjacent normal esophageal tissues. (A) Log2 ratios of miR-486-5p expression levels in 35 paired ESCC tissues (T) to adjacent normal esophageal tissues (N). (B) The relative expression of miR-486-5p in ESCC (T) and adjacent normal esophageal tissues $(\mathrm{N})$. Values presented are the mean \pm standard deviation of three independent experiments $\left({ }^{*} \mathrm{P}<0.05\right)$.

A

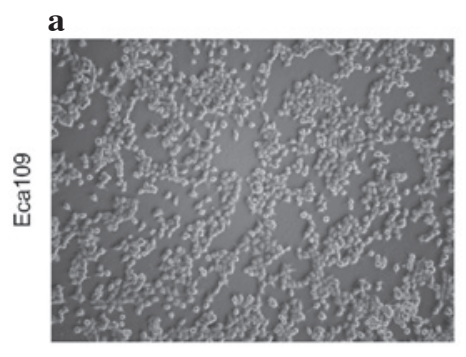

c

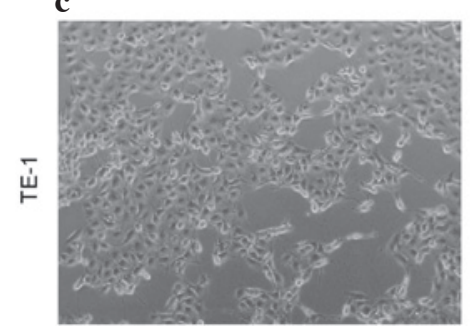

b

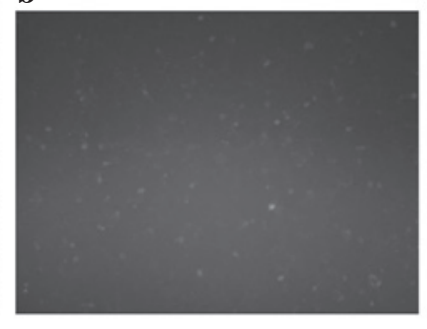

d

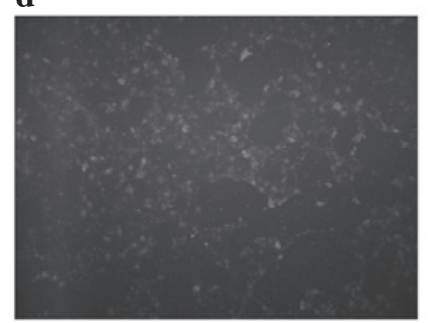

B

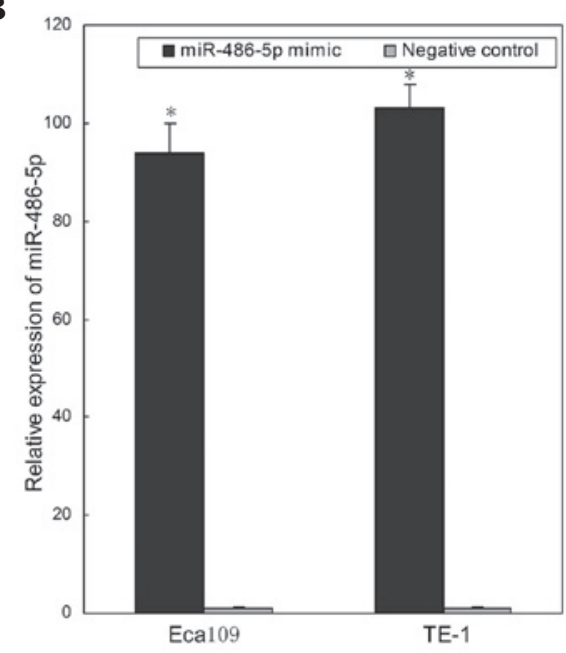

Figure 2. Analysis of transfection efficiency and miR-486-5p expression levels by fluorescence microscopy and reverse transcription-quantitative polymerase chain reaction. (Aa-Ab) The transfection efficiency was $\sim 80$ and $~ 85 \%$ in Eca109 and TE-1 cells, respectively. Images of (Aa) Eca109 cells transfected with the Fam-labeled negative control. (Ab) Eca109 cells exhibiting green fluorescence $6 \mathrm{~h}$ post-transfection. (Ac) Images of TE-1 cells transfected with the Fam-labeled negative control. (Ad) TE-1 cells exhibiting green fluorescence $6 \mathrm{~h}$ after transfection. (B) The fold changes of miR-486-5p expression in Eca109 and TE-1 cells treated with miR-486-5p mimics or the negative control were determined $24 \mathrm{~h}$ post-transfection. Values presented are the mean \pm standard deviation of three independent experiments ( $\mathrm{P}<0.05)$.

Overexpression ofmiR-486-5p suppressed ESCC cell migration in vitro. The effects of overexpression of miR-486-5p on cell migration of ESCC cells in vitro was determined by the use of a wound scratch assay. As shown in Fig. 3, the wound widths of Eca109 and TE-1 cells transfected with miR-486-5p mimics were wider $(\mathrm{P}<0.05)$ compared with those of the negative control group at $24 \mathrm{~h}$. Thus, it was indicated that upregulation of miR-486-5p inhibited the cell migration of ESCC cells.

miR-486-5p mimics inhibited cell proliferation. The impact of miR-486-5p on cell proliferation in ESCC cells was analyzed using an MTT assay. The OD values of the miR-486-5p mimic and negative control groups were measured at $0,24,48$ and $72 \mathrm{~h}$ after transfection. The results showed that the proliferation of Eca109 cells decreased by 9.09, 15.71 and 19.84\% (all $\mathrm{P}<0.05$ ) at the respective aforementioned time-points, while the proliferation of TE-1 cells decreased by $8.89,14.47$ and $19.17 \%$ (all $\mathrm{P}<0.05$; Fig. 4). These results suggest that the upregulation of miR-486-5p by mimics suppressed proliferation of ESCC cells in vitro.

Restoration of miR-486-5p induced ESCC cell apoptosis. To determine the effects of miR-486-5p on ESCC cell apoptosis, flow cytometry was used to determine the apoptosis rates after transfection. As shown in Fig. 5, apoptosis rates of Eca109 cells transfected with miR-486-5p mimics and those of the negative control were 9.7 and $3.4 \%$, respectively $(\mathrm{P}<0.01) 48 \mathrm{~h}$ after transfection. The apoptosis rates of TE- 1 cells were 10.4 and $4.4 \%$, respectively $(\mathrm{P}<0.01)$ subsequent to transfection (Fig. 5). Thus suggesting that the restoration of miR-486-5p expression levels induced ESCC cell apoptosis.

\section{Discussion}

Carcinogenesis involves the activation of numerous oncogenes and anti-oncogenes. In the complex network involving the 

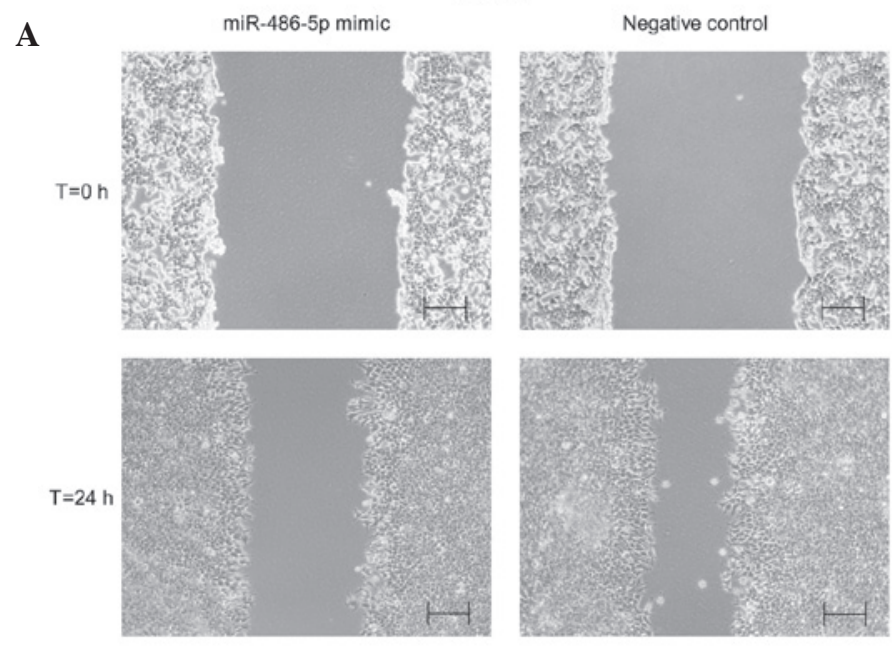

TE-1
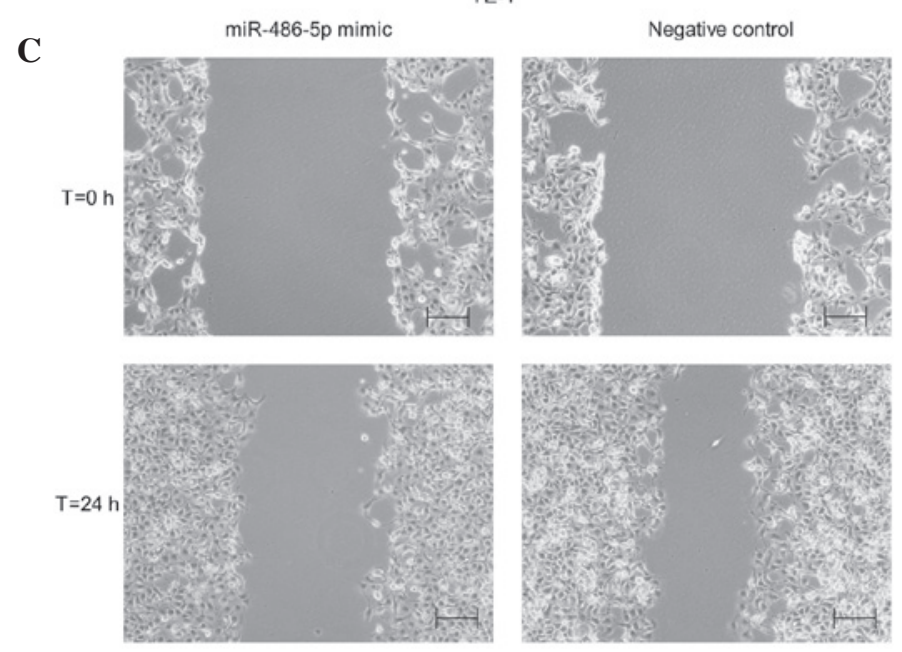

Negative control

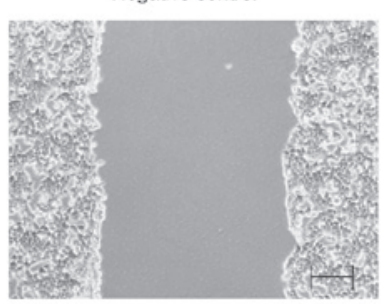

Negative control

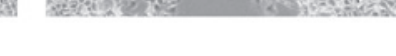

Figure 3. Wound scratch assay for Eca109 and TE-1 cells 24 h post-transfection. (A) Images of the Eca109 cells transfected with miR-486-5p mimics or negative control 0 and $24 \mathrm{~h}$ after the scratches were made at the same point. (B) Quantification of the migration distances ( $\mu \mathrm{m}$ ) in Eca109 cells using a standard caliper $(\mathrm{P}<0.05)$. (C) Images of the TE-1 cells transfected with miR-486-5p mimics or with the negative control 0 and $24 \mathrm{~h}$ after the scratches were made at the same point. (D) Quantification of the migration distances $(\mu \mathrm{m})$ in TE-1 cells using a standard caliper. Values presented are the mean \pm standard deviation of three independent experiments $\left({ }^{*} \mathrm{P}<0.05\right)$.
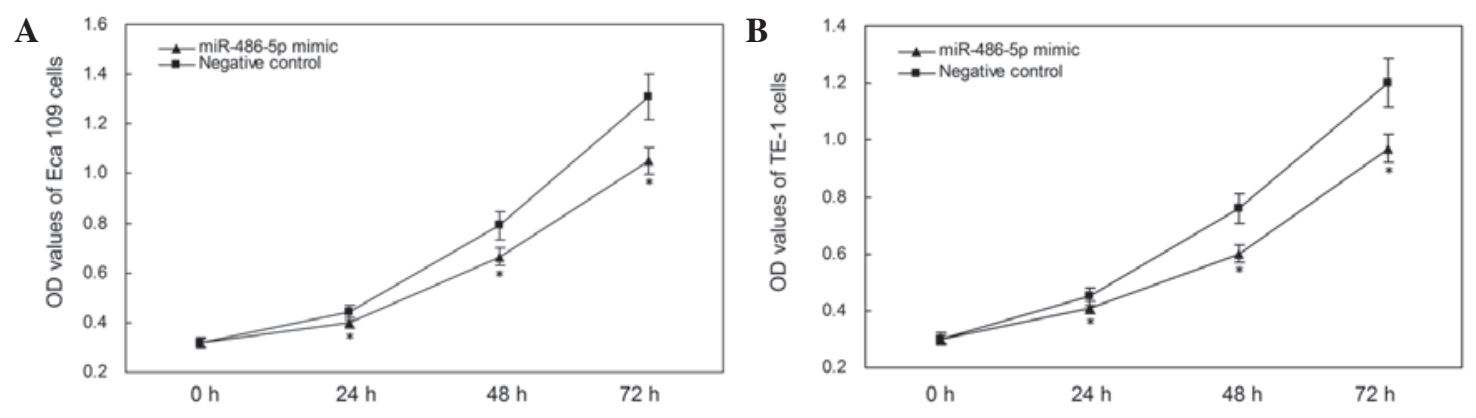

Figure 4. MTT assay for cell proliferation of Eca109 and TE-1 cells transfected with miR-486-5p mimics or the negative control. (A) Cell proliferation of Eca109 cells. (B) Cell proliferation of TE-1 cells. Values presented are the mean \pm standard deviation of three independent experiments ("P<0.05).

regulation of oncogenes and anti-oncogenes, miRNAs are associated with gene regulation at the transcriptional and translational level through base-pairing to complementary mRNA sequences in their target genes $(18,19)$. A miRNA may fulfil the role of an anti-oncogene or an oncogene by regulating the levels of oncogenes or anti-oncogenes (9). miRNAs serve important
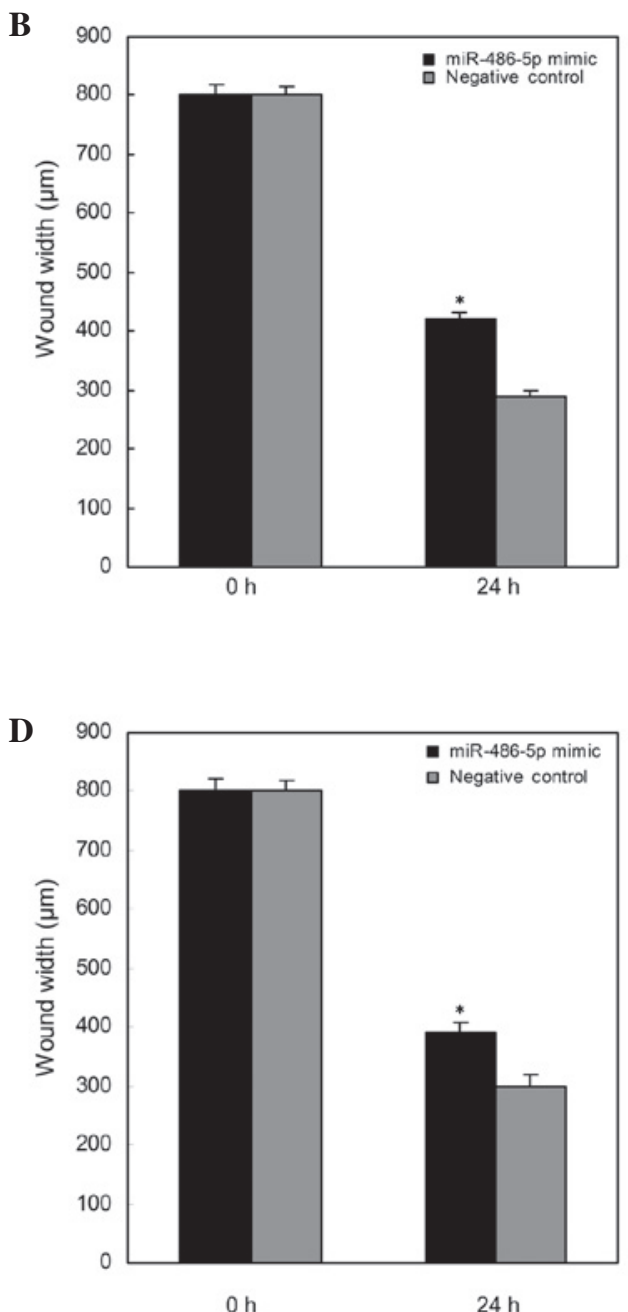

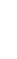


A

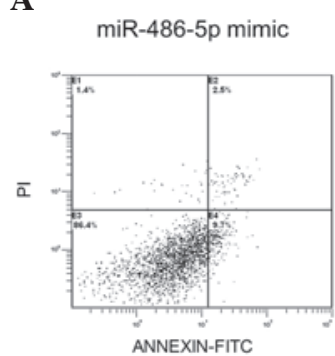

Eca109

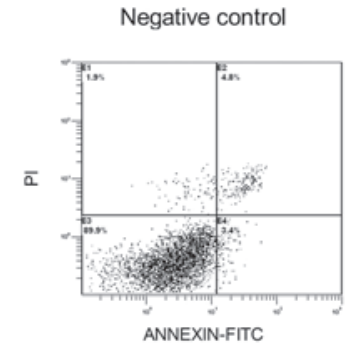

B

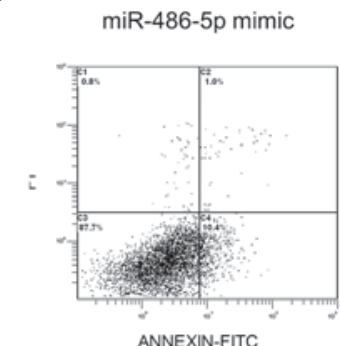

TE-1

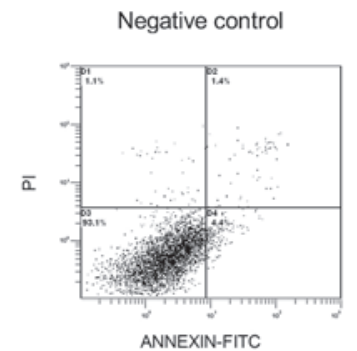

C

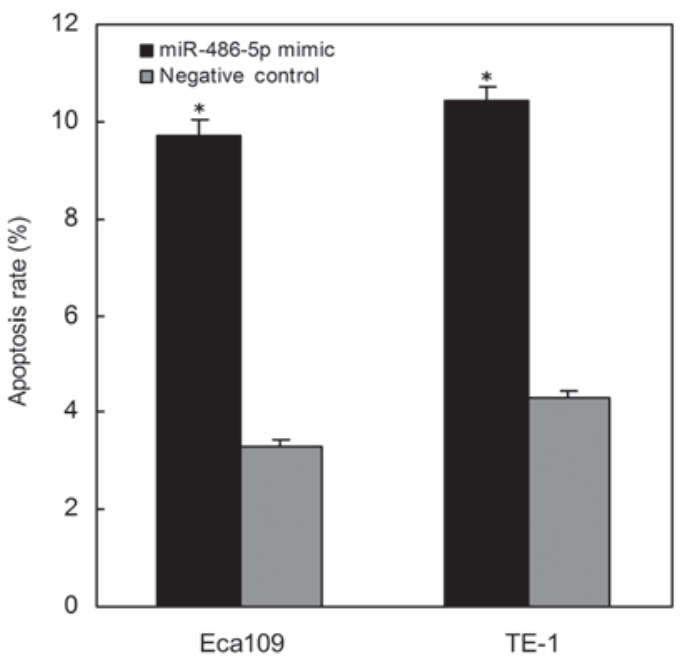

Figure 5. Flow cytometry analysis for cell apoptosis of Eca109 and TE-1 cells transfected with miR-486-5p mimics or the negative control. (A) Eca109 cells transfected with miR-486-5p mimics and negative control. (B) TE-1 cells transfected with miR-486-5p mimics and negative control. (C) Comparison of the apoptosis rates of Eca109 and TE-1 cells transfected with miR-486-5p mimics and the negative control. Data are presented as the mean \pm standard deviation of three measurements $\left({ }^{*} \mathrm{P}<0.01\right)$.

miR-205 (31). By contrast, downregulation of miR-375 (27), miR-205, miR-203, miR-125b, miR-100 and miR-27b (29) have been detected in ESCC. Furthermore, numerous miRNAs were found to serve oncogenic or anti-oncogenic roles, including the facilitation of ESCC growth by miR-21 through targeting PTEN and PDCD4 $(28,32)$, in addition to the ability of miR-145, miR-133a and miR-133b to converge to target Fascin 1, reducing cell growth and invasion (33). Furthermore, miR-210 targets FGFRL1, exerting a negative effect on the cell cycle and proliferation (34), while miR-296 contributes to ESCC growth by targeting cell CCND1 and p27 (35). Finally, miR-593 may contribute to carcinogenesis through serine/threonine-protein kinase (36).

The downregulation of miR-486-5p is a frequent molecular event in certain human malignances (14-16,37-40). Furthermore, miR-486-5p may function as tumor suppressor through contributing to the progression and metastasis of NSCLC by targeting ARHGAP5 (14), in addition to the fact that miR-486-5p exerts its antiproliferative function by directly downregulating PIM-1 expression in breast cancer cells (15), miR-486-5p suppresses tumor growth by targeting PIK3R1 in hepatocellular carcinoma (16). However, the expression and role of miR-486-5p in ESCC has yet to be elucidated.

To determine the expression and role of miR-486-5p in ESCC, RT-qPCR was used to quantify miR-486-5p expression levels in 35 cases of ESCC tissues and paired normal tissues. The present study showed that miR-486-5p expression levels were significantly downregulated in ESCC tissues, compared with the expression levels in paired normal esophageal tissues. The effects of miR-486-5p on ESCC cell migration, proliferation and apoptosis were then analyzed by transfection of ESCC cell lines with synthetic miR-486-5p mimics. Transfection of miR-486-5p mimics into the ESCC cell lines Eca109 and TE-1, inhibited cellular proliferation, migration and induced apoptosis, compared with the negative control group. The data indicates that miR-486-5p may be characterized as an anti-oncogene in ESCC by inhibiting cellular proliferation and migration, and promoting cellular apoptosis. Further identification of miR-486-5p target genes is warranted to clarify the mechanism of action of miR-486-5p in ESCC.

In conclusion, the present study revealed that miR-486-5p was downregulated in ESCC and served a vital anti-oncogenic role in ESCC by affecting cellular migration, proliferation and apoptosis. Further studies are required to determine the mechanism of action of miR-486-5p in ESCC.

\section{References}

1. Enzinger PC and Mayer RJ: Esophageal cancer. N Engl J Med 349: 2241-2252, 2003.

2. Kollarova H, Machova L, Horakova D, Janoutova G and Janout V: Epidemiology of esophageal cancer-an overview article. Biomed Pap Med Fac Univ Palacky Olomouc Czech Repub 151: 17-20, 2007.

3. Bohanes P, Yang D, Chhibar RS, Labonte MJ, Winder T, Ning Y, Gerger A, Benhaim L, Paez D, Wakatsuki T, et al: Influence of sex on the survival of patients with esophageal cancer. J Clin Oncol 30: 2265-2272, 2012 
4. Steyerberg EW, Neville B, Weeks JC and Earle CC: Referral patterns, treatment choices and outcomes in locoregional esophageal cancer: A population-based analysis of elderly patients. J Clin Oncol 25: 2389-2396, 2007.

5. Zhao P, Dai M, Chen W and Li N: Cancer trends in China. Jpn J Clin Oncol 40: 281-285, 2010.

6. Liu J, Xie X, Zhou C, Peng S, Rao D and Fu J: Which factors are associated with actual 5-year survival of oesophageal squamous cell carcinoma? Eur J Cardiothorac Surg 41: e7-e11, 2012.

7. Jiang L, Liu X, Chen Z, Jin Y, Heidbreder CE, Kolokythas A, Wang A, Dai Y and Zhou X: MicroRNA-7 targets IGF1R (insulin-like growth factor 1 receptor) in tongue squamous cell carcinoma cells. Biochem J 432: 199-205, 2010.

8. Soeda S, Ohyashiki JH, Ohtsuki K, Umezu T, Setoguchi Y and Ohyashiki K: Clinical relevance of plasma miR-106b levels in patients with chronic obstructive pulmonary disease. Int J Mol Med 31: 533-539, 2013.

9. Xiong Y, Zhang L, Holloway AK, Wu X, Su L and Kebebew E: MiR-886-3p regulates cell proliferation and migration and is dysregulated in familial non-medullary thyroid cancer. PLoS One 6: e24717, 2011

10. Ha TY: MicroRNAs in human diseases: From cancer to cardiovascular disease. Immune Netw 11: 135-154, 2011.

11. Shibuya $H$, Iinuma $H$, Shimada $R$, Horiuchi A and Watanabe $T$ : Clinicopathological and prognostic value of microRNA-21 and microRNA-155 in colorectal cancer. Oncology 79: 313-320, 2010.

12. Akao Y, Noguchi S, Iio A, Kojima K, Takagi T and Naoe T: Dysregulation of microRNA-34a expression causes drug-resistance to 5-FU in human colon cancer DLD-1 cells Cancer Lett 300: 197-204, 2011.

13. Tili E, Michaille JJ, Wernicke D, Alder H, Costinean S, Volinia S and Croce CM: Mutator activity induced by microRNA-155 (miR-155) links inflammation and cancer. Proc Natl Acad Sci USA 108: 4908-4913, 2011

14. Wang J, Tian X, Han R, Zhang X, Wang X, Shen H, Xue L, Liu Y, Yan X, Shen J, et al: Downregulation of miR-486-5p contributes to tumor progression and metastasis by targeting protumorigenic ARHGAP5 in lung cancer. Oncogene 33: 1181-1189, 2014.

15. Zhang G, Liu Z, Cui G, Wang X and Yang Z: MicroRNA-486-5p targeting PIM-1 suppresses cell proliferation in breast cancer cells. Tumour Biol 35: 11137-11145, 2014.

16. Huang XP, Hou J, Shen XY, Huang CY, Zhang XH, Xie YA and Luo XL: MicroRNA-486-5p, which is downregulated in hepatocellular carcinoma, suppresses tumor growth by targeting PIK3R1. FEBS J 282: 579-594, 2015.

17. Livak KJ and Schmittgen TD: Analysis of relative gene expression data using real-time quantitative PCR and the 2(-Delta Delta C(T)) Method. Methods 25: 402-408, 2001

18. Jing Q, Huang S, Guth S, Zarubin T, Motoyama A, Chen J, Di Padova F, Lin SC, Gram H and Han J: Involvement of microRNA in AU-rich element-mediated mRNA instability. Cell 120: 623-634, 2005.

19. Guo S, Bai H, Megyola CM, Halene S, Krause DS, Scadden DT and $\mathrm{Lu} \mathrm{J}$ : Complex oncogene dependence in microRNA-125a-induced myeloproliferative neoplasms. Proc Natl Acad Sci USA 109: 16636-16641, 2012.

20. Bhattacharyya S, Balakathiresan NS, Dalgard C, Gutti U, Armistead D, Jozwik C, Srivastava M, Pollard HB and Biswas R: Elevated miR-155 promotes inflammation in cystic fibrosis by driving hyperexpression of interleukin-8. J Biol Chem 286 : 11604-11615, 2011.

21. Lucotti S, Rainaldi G, Evangelista M and Rizzo M: Fludarabine treatment favors the retention of miR-485-3p by prostate cancer cells: Implications for survival. Mol Cancer 12: 52, 2013.

22. Sarver AL, French AJ, Borralho PM, Thayanithy V, Oberg AL, Silverstein KA, Morlan BW, Riska SM, Boardman LA, Cunningham JM, et al: Human colon cancer profiles show differential microRNA expression depending on mismatch repair status and are characteristic of undifferentiated proliferative states. BMC Cancer 9: 401, 2009.

23. Zhai Q, Zhou L, Zhao C, Wan J, Yu Z, Guo X, Qin J, Chen J and Lu R: Identification of miR-508-3p and miR-509-3p that are associated with cell invasion and migration and involved in the apoptosis of renal cell carcinoma. Biochem Biophys Res Commun 419: 621-626, 2012.
24. Bentwich I, Avniel A, Karov Y, Aharonov R, Gilad S, Barad O, Barzilai A, Einat P, Einav U, Meiri E, et al: Identification of hundreds of conserved and nonconserved human microRNAs. Nat Genet 37: 766-770, 2005

25. Liu X, Yu J, Jiang L, Wang A, Shi F, Ye H and Zhou X MicroRNA-222 regulates cell invasion by targeting matrix metalloproteinase 1 (MMP1) and manganese superoxide dismutase 2 (SOD2) in tongue squamous cell carcinoma cell lines. Cancer Genomics Proteomics 6: 131-139, 2009.

26. Tian Y, Luo A, Cai Y, Su Q, Ding F, Chen H and Liu Z: MicroRNA-10b promotes migration and invasion through KLF4 in human esophageal cancer cell lines. J Biol Chem 285: 7986-7994, 2010.

27. Mathé EA, Nguyen GH, Bowman ED, Zhao Y, Budhu A, Schetter AJ, Braun R, Reimers M, Kumamoto K, Hughes D, et al: MicroRNA expression in squamous cell carcinoma and adenocarcinoma of the esophagus: Associations with survival. Clin Cancer Res 15: 6192-6200, 2009.

28. Hiyoshi Y, Kamohara H, Karashima R, Sato N, Imamura Y, Nagai Y, Yoshida N, Toyama E, Hayashi N, Watanabe M and Baba H: MicroRNA-21 regulates the proliferation and invasion in esophageal squamous cell carcinoma. Clin Cancer Res 15: 1915-1922, 2009.

29. Feber A, Xi L, Luketich JD, Pennathur A, Landreneau RJ, Wu M, Swanson SJ, Godfrey TE and Litle VR: MicroRNA expression profiles of esophageal cancer. J Thorac Cardiovasc Surg 135: 255-260, 2008.

30. Ogawa R, Ishiguro H, Kuwabara Y, Kimura M, Mitsui A, Katada T, Harata K, Tanaka T and Fujii Y: Expression profiling of micro-RNAs in human esophageal squamous cell carcinoma using RT-PCR. Med Mol Morphol 42: 102-109, 2009.

31. Matsushima K, Isomoto H, Kohno S and Nakao K: MicroRNAs and esophageal squamous cell carcinoma. Digestion 82: 138-144, 2010.

32. Ma WJ, Lv GD, Tuersun A, Liu Q, Liu H, Zheng ST, Huang CG, Feng JG, Wang X, Lin RY, et al: Role of microRNA-21 and effect on PTEN in Kazakh's esophageal squamous cell carcinoma. Mol Biol Rep 38: 3253-3260, 2011.

33. Kano M, Seki N, Kikkawa N, Fujimura L, Hoshino I, Akutsu Y, Chiyomaru T, Enokida H, Nakagawa $\mathrm{M}$ and Matsubara $\mathrm{H}$ : miR-145, miR-133a and miR-133b: Tumor-suppressive miRNAs target FSCN1 in esophageal squamous cell carcinoma. Int J Cancer 127: 2804-2814, 2010.

34. Tsuchiya S, Fujiwara T, Sato F, Shimada Y, Tanaka E, Sakai Y, Shimizu K and Tsujimoto G: MicroRNA-210 regulates cancer cell proliferation through targeting fibroblast growth factor receptor-like 1 (FGFRL1). J Biol Chem 286: 420-428, 2011.

35. Hong L, Han Y, Zhang H, Li M, Gong T, Sun L, Wu K, Zhao Q and Fan D: The prognostic and chemotherapeutic value of miR-296 in esophageal squamous cell carcinoma. Ann Surg 251: 1056-1063, 2010.

36. Ito T, Sato F, Kan T, Cheng Y, David S, Agarwal R, Paun BC, Jin Z, Olaru AV, Hamilton JP, et al: Polo-like kinase 1 regulates cell proliferation and is targeted by miR-593* in esophageal cancer. Int J Cancer 129: 2134-2146, 2011

37. Shen J, Liu Z, Todd NW, Zhang H, Liao J, Yu L, Guarnera MA, Li R, Cai L, Zhan M and Jiang F: Diagnosis of lung cancer in individuals with solitary pulmonary nodules by plasma microRNA biomarkers. BMC Cancer 11: 374, 2011.

38. Tan X, Qin W, Zhang L, Hang J, Li B, Zhang C, Wan J, Zhou F, Shao K, Sun Y, et al: A 5-microRNA signature for lung squamous cell carcinoma diagnosis and hsa-miR-31 for prognosis. Clin Cancer Res 17: 6802-6811, 2011

39. Ragusa M, Majorana A, Statello L, Maugeri M, Salito L, Barbagallo D, Guglielmino MR, Duro LR, Angelica R, Caltabiano R, et al: Specific alterations of microRNA transcriptome and global network structure in colorectal carcinoma after cetuximab treatment. Mol Cancer Ther 9: 3396-3409, 2010.

40. Bansal A, Lee IH, Hong X, Anand V, Mathur SC, Gaddam S, Rastogi A, Wani SB, Gupta N, Visvanathan M, et al: Feasibility of mcroRNAs as biomarkers for Barrett's Esophagus progression: A pilot cross-sectional, phase 2 biomarker study. Am J Gastroenterol 106: 1055-1063, 2011. 